\title{
The Practical Study on Task-based Teaching in Improving Students' Listening and Speaking Ability
}

\section{Chen Yuexia}

Department of Foreign Language Teaching, Taishan University, Tai'an, Shandong Province, China, 271000

Keywords: task-based teaching method; College English; listening and speaking ability; practice

\begin{abstract}
As the trend of economic globalization is gradually strengthened, the scope of intercultural communication is gradually expanding, and the demand for applied talents in the market is also increasing. But in the process of training English talents, more and more traditional rigid teaching modes still exist in colleges and universities. Students' English ability is more reflected in reading, while listening and speaking abilities are very limited, even falling into the learning dilemma of "dumb English". In the face of this malpractice, College English should explore more practical teaching ways in teaching and training students' listening and speaking abilities. Based on this, this paper starts from the basic content of task-based teaching method, and explores the practicality of teaching.
\end{abstract}

\section{An overview of task-based teaching method}

Task-based teaching refers to the teaching practice, teachers focus on specific teaching objectives, design operational learning task specific, and guide the students according to the requirement of the task, give full play to the initiative, through the expression, communication, negotiation, interpretation, asked in various ways to complete the task, so as to achieve a kind of teaching mode the purpose of the study and master knowledge [1].

College students not only have a certain basic English, but also have the ability to think independently and explore independently. But from the current teaching mode of view, although the curriculum reform of students' autonomous learning to provide a certain amount of space, but the majority of students still will focus on learning English on reading, writing, and ignore the listening and speaking training, this way is very easy to fall into the trap of "dumb English", which is the lack of students English language in daily communication is difficult to timely access to information, understanding, obstacle of English application. Besides, teachers also lack enough attention to students' listening training. Some teachers emphasize students' vocabulary and reading volume. Listening and speaking training depends entirely on students' autonomy. The present situation of teaching and learning will inevitably affect the development of College Students' English comprehensive ability. Task-based language teaching is a language teaching model that emerged in the 1980s. It accumulated rich experience in language teaching in the long term teaching practice. In College English listening and speaking teaching, task-based teaching method mainly has the following characteristics: first, the task is the carrier of students' listening and speaking ability training, to break the traditional teaching mode in the teaching materials follow the prescribed order in accordance with the process of students' listening and speaking training stereotype; second, in the design and analysis of task, teachers can break through the limitations of teaching materials, teaching material the use of English, magazine articles, novels, posters, brochures, business letters, maps, English film and television information of authentic language materials, construct vivid and interesting learning environment for the students; third, in the training of listening and speaking, the teacher to student expression as the key point, to encourage students to English blurt out, to avoid excessive emphasis on English is correct specification, training, and guide students to first overcome psychological barriers, dare to use English to express themselves in fourth; In task teaching, students are the main body of listening and speaking training. They can explore tasks according to their own experience and way of thinking, and then complete their learning tasks independently [2]. 
Task is the core of task-based language teaching. In the process of designing tasks, College English teachers should analyze comprehensively. They should not only infiltrate learning contents, but also reflect their effective guidance to students' listening and speaking abilities. Based on this, in the College English teaching practice, teachers for the task design should follow the following principles: first, the authenticity of the task is not castles in the air, it is close to the students' learning materials and learning guidance, therefore, teachers should be good at mining data from life, the English Listening training linked to real life, to stimulate students' interest in participating; second, coherence, listening and speaking training process requires multiple tasks are arranged and combined in the design, teachers should use a central theme, the design of different levels and the difficulty of the task, let the students in the training of listening and speaking is relatively independent, to achieve the purpose of interrelated tasks; third, comprehensive training of listening and speaking tasks should be the unity of form and function of English listening and speaking practice, the knowledge and interest. Fourth, moderate difficulty, teachers should ensure that listening and speaking tasks can not only meet students' English basis, but also have certain challenges and images, so as to stimulate students' driving force.

\section{The application significance of task-based teaching method in English listening and speaking teaching in colleges and universities}

\subsection{Perfect the teaching mode of College English}

The training of listening and speaking is the only way which must be passed to learn a language, one that is an important embodiment of language application, on the other hand, the training of listening and speaking, the individual sense of language and the flexibility of thinking can be cultured, therefore, in the teaching of College English teachers should start from the improvement of students' comprehensive ability of English listening and speaking training will angle. And reading and writing training in the same position. The long-term existence of the traditional language teaching model makes the students lack the initiative for the training of English listening and speaking ability. As a new teaching idea, task teaching has broken the traditional teaching mode. In the task of exploration, not only emphasizes the students' initiative, also can use a variety of ways to enrich the language materials, training to expand the breadth and depth of listening and speaking content, let students gain practical training opportunities in the situation, and gradually reverse the result of the traditional teaching mode of thinking, realize the teaching of English listening and speaking to listen to promote that, to say in order to promote listening, reading and writing to promote listening[3].

\subsection{Stimulate students' interest in English learning}

Students are the main body of task teaching. In practice, students can explore the key points of their tasks through cooperation and communication with others, and listen attentively in the communication, dare to express, and realize the pleasure of teamwork. The task of teaching can create a lively atmosphere in the classroom, the group can share their own learning experience, discuss heard pronunciation problems, inquiry task solution, in harmony in the scope of each one airs his own views, to maximize student participation. Encouraging communication is the key to improve students' confidence. In task exploration, students' mind is free to play. Meanwhile, under the encouragement and drive of team members, it breaks through the expression barriers of timidity and inferiority, and improves the smoothness of expression in listening and speaking.

\subsection{Improve the students' ability to use the comprehensive language}

The main purpose of the task teaching method is to improve the students' comprehensive use of language, so that students can be more smooth and accurate in the communication of language. Language reflects the comprehensive expression of individual ability, task in the exploration process, the thinking ability of students to get training, improve the ability to respond to language analysis; ability training, explore the differences between Chinese and English expression, improve 
the ability of cross-cultural communication; the development of innovation ability, in the task analysis, students can play the subjective initiative, exploring different solutions, innovative learning methods, improve students' awareness of English application[4].

\section{Task-based teaching method improves the practice path of students' listening and speaking ability}

\subsection{The design of the task before the course}

In preparing lessons, teachers should carefully design tasks through the analysis of students' characteristics and the integration of teaching tasks, so as to ensure the smooth exploration and analysis of follow-up tasks. In listening and speaking training, the design of tasks usually includes routine tasks and targeted tasks. The basic task of routine tasks is the daily listening and speaking training, such as in the classroom, teachers can provide BBC and VOA broadcasts in English listening materials for students, English movie clips, 46 listening training materials, let students imperceptibly by listening edification in daily teaching; the targeted task refers to teachers combined with a specific theme for the training of listening and speaking, students design task, let the students in the task driven, flexible grasp the common expression of a situation that expression. For example, in the training of "interview" as a theme, teachers can combine English materials to design interviewing situations related tasks for students, so that students can prepare materials, preset scenarios, explore problems and practice expressions through group cooperation, and finally finish tasks.

\subsection{Task exploration in the course}

In classroom teaching, the implementation of task-based teaching needs combinations of different types and levels of task chains, so that students can increase listening and speaking skills and exercise opportunities and improve cross-cultural communication and expression effects in interlocking teaching tasks.

\subsubsection{Import tasks}

Before the beginning of the teaching, the teacher should introduce the cooperative task according to the information before the class. Taking the cooperation task of interview as an example, in the process of introduction, teachers first used the employment data of college students in recent years to explain for students, the focus of current society is "difficult employment of college students", and thus leads to the relationship between interview and employment. Then, teachers use teaching guidance to share their interview experience based on their career planning, and from the perspective of intercultural communication, draw common problems in English interview. Finally, the task is taught to the groups so that students will continue to discuss and analyze the theme of "interview"[5].

\subsubsection{Discussion on the task}

In the course of students' discussion, teachers should play their own leading role and guide the students to analyze the task. In the "interview" task, teachers introduced American classic "The Pursuit of Happyness" for the students, and according to the movie actor Chris Gardiner a classic interview scene, let the student to the interviewer and interviewee's answer in-depth analysis. Students need to discuss the problems in the task analysis including interview etiquette, interview questions for interview, and the attitude of the interviewer to capture the hidden information, the content is not only can be used as listening materials, but also can provide reference for the future work of the students interview.

\subsubsection{Listening training}

The training of listening and speaking abilities can not be limited to discussion, but should be deeply applied to practice. Only in task teaching, can we provide enough high-quality listening materials for students to be able to effectively exercise their listening and speaking abilities. In the 
task analysis of "interview", teachers use multimedia devices to provide students with a listening material for interviewing, and use questions to provide direction for students' listening information capture. And guide students through group cooperation, design the answer strategy, improve the ability to deal with English interview [6].

\subsubsection{Oral expression}

Oral expression is an important way of information output. In listening and speaking training, teachers should add oral training links to tasks, instruct teams to simulate task situations and improve listening and speaking abilities. In the process of "interview" task practice, teachers can instruct each group of students to simulate the interview scene, which is not only conducive to create a lively and interesting learning atmosphere, but also inspire students' enthusiasm for participation, and achieve internalization of knowledge in participation.

\subsection{After-class task design}

The post - class task is an important link to consolidate the effect of the students' task and to cultivate the students' self-learning ability. In teaching design, teachers for students to avoid monotonous language tired, should guarantee the class task of novelty and practicality, such as the investigation on students' interview, let students share their meet in the interview questions, and design related tasks, such as "What do you know about us?" "Why do you want to work here?", "What kind of salary are you looking for?", these problems in the workplace are of high frequency, although some students have to prepare before the interview on these issues, designs a comprehensive answer. But in the task of teaching, teachers should also from training students listening and speaking ability, set up interviews for students, allowing students to re sort of these problems, combining with the analysis of each link level, the task in the classroom, improve the degree of completion of the task of learning, improve the teaching effect of consolidation.

\section{Evaluation after class}

The evaluation of the task teaching method is an important part of the teaching practice. The process of task teaching is the process of reflecting the students' subjectivity. In the evaluation, teachers should evaluate the completion of the students' tasks from the perspectives of knowledge, ability and emotion, according to the requirements of the new curriculum standards. For example, in the "interview task design", "design teachers to grasp the common English sentence in the interview expressed clearly reflects the different cultural etiquette interview process, experience of cross-cultural ability situation" training objectives; in cooperative learning, the training goal of active participation in the cooperation consciousness and ability for students system. In view of these evaluation criteria, teachers should set up evaluation criteria for students through task analysis, situational construction and teaching observation, so as to ensure the guiding role of tasks. In addition, in carrying out the task-based teaching method, teachers should not be excluded in the evaluation of students, should be opposite according to their performance in the cooperative task, reflect the cooperation on their listening and speaking ability and group and comprehensive summary, and embodies the teaching evaluation and objectivity.

Four, concluding remarks

In a word, task-based teaching is not only an advanced teaching idea, but also an effective teaching method. In College English listening and speaking training, teachers should cultivate applied talents from the point of view, the introduction of learning tasks, encourage students to work together in the team, collecting information, discussion and analysis tasks, formulate the plan, in the process of practice, students' autonomous learning ability, cooperative ability has been fully aroused, this it is very important for the cultivation of English talents.

\section{Acknowledgements}

Practical Research on the Application of Task-based Teaching in Listening \& Speaking Class 
(Research Project of Social Science Planning and Managing of Shan Dong Province, No. 13CWJZ13)

\section{References}

[1] Li-Lan W U. How to Improve students' Listening and Speaking Ability in English Intensive Reading Teaching in the University-Taking Bijie University as an Example[J]. Overseas English, 2013.

[2] Wang J Q, Guo Y. A Study on How to Improve College Students' Listening and Speaking Ability [J]. Journal of Changchun Normal University, 2010.

[3] Deng H. A Research on How to Improve Students' Listening and Speaking Skills from the Prospective of Applied Talent Cultivation-A Case of Liaoning University of International Business and Economics [J]. Journal of Changchun University, 2014.

[4] Wang Y H, Zhen Q, Chao L I. On the Training of the Second Classroom of College English Listening and Speaking Ability [J]. Journal of Hubei Correspondence University, 2016.

[5] Tian J Y. Some Attempts at Improving Students' Ability of English Listening and Speaking [J]. Journal of Anhui Agricultural University, 2005.

[6] Wang H Y. How to Improve Students' Listening and Speaking Abilities of English [J]. Journal of Shanxi Radio \& Tv University, 2005. 